\title{
New species of Eugerres from the Usumacinta Province, México and Guatemala with a redescription of $E$. mexicanus (Steindachner, 1863) (Teleostei: Gerreidae)
}

\author{
Adrián F. González-Acosta ${ }^{1,2}$ and Rocío Rodiles-Hernández ${ }^{1}$
}

Eugerres castroaguirrei, new species is described from the río Grijalva-Usumacinta basin of southeastern Mexico and northern Guatemala. Eugerres castroaguirrei and E. mexicanus are distinguishable from their marine estuarine congeners by the dorsalfin origin posterior to the insertion of the pectoral and pelvic fins, a shorter and broad based supraoccipital crest, and a distinct geographic distribution restricted to freshwater habitats. Eugerres castroaguirrei differs from E. mexicanus by diagnostic characters of the body skeleton: anterior process of supraoccipital convex, infraorbital 1 with foramen, premaxillary ascending process developed with margins curved, pharyngeal plate granular and not serially arranged, and dorsal and anal fin-rays reduced. Likewise, E. castroaguirrei is characterized by an oblong and laterally thicker body (37.6-58.5\% HL); greater body depth $(33.8-42.1 \% \mathrm{SL})$, and eye diameter $(23.3-31.6 \% \mathrm{HL})$; in addition to 16 significant morphometric characters: length of the second dorsal-fin spine 23.2-34.2\% SL; depressed second dorsal-fin spine (extending to base of third to fourth dorsal-fin rays); length of second anal-fin spine 11.1-20.6\% SL, depressed second anal-fin spine extending to the base of third to fourth anal-fin rays not reaching the distal point of last anal-fin ray; pelvic-fin spine length $49.7-65.0 \%$ in the first pelvic-fin ray length.

Eugerres castroaguirrei, es descrita como especie nueva de la cuenca del sistema de ríos Grijalva-Usumacinta, en el sureste de México y norte de Guatemala. Eugerres castroaguirrei y E. mexicanus se distinguen de sus congéneres marino estuarinos por el origen de su aleta dorsal que es posterior a la inserción de las aletas pectorales y pélvicas, así como por su cresta supraoccipital de longitud corta y base amplia, además de una distribución restringida a ambientes dulceacuícolas. Eugerres castroaguirrei se distingue de E. mexicanus mediante caracteres óseos diagnósticos como: proceso anterior del supraoccipital convexo, presencia de un foramen en el infraorbital 1, proceso ascendente del premaxilar desarrollado y con márgenes curvos, las placas faríngeas con dientes granulares desarreglados y los soportes de las aletas dorsal y anal reducidos. Asimismo, $E$. castroaguirrei se caracteriza por tener un cuerpo alargado y lateralmente comprimido cuyo grosor representa 37.6-58.5\% de la longitud cefálica [LC]; la altura del cuerpo comprendida entre 33.8-42.1\% de la longitud patrón [LP] y el diámetro ocular 23.3$31.6 \%$ de la LC; además de 16 caracteres de tipo morfométrico: longitud de la segunda espina dorsal que representa 23.2-34.2\% de la LP; segunda espina dorsal que cuando esta plegada se extiende hasta la base del tercer y cuarto radio dorsal; longitud de la segunda espina anal que comprende 11.1-20.6\% de la LP; segunda espina anal que plegada se extiende hasta la base del tercer y cuarto radio anal, aunque no alcanza la porción distal del último radio anal; y la longitud de la espina de la aleta pélvica que comprende 49.7-65.0\% de la longitud del primer radio pélvico.

Key words: Grijalva-Usumacinta basin, Mexican mojarra, Pichincha, Taxonomy, Vicarious species.

\section{Introduction}

The commonly named 'mojarras' of the family Gerreidae comprise a group of fish distributed along the subtropical and tropical coasts areas of the world's ocean. In the Americas, the family consists of 22 valid species, classified in four genera (Nelson et al., 2004): Gerres Quoy \& Gaimard, 1824; Diapterus Ranzani, 1840; Eucinostomus Baird \& Girard, 1855, and
Eugerres Jordan \& Evermann, 1927. Most of the species inhabit coastal lagoons and estuaries with sandy or muddy bottoms bordered by mangroves; however, they occasionally enter river mouths. It has been thought that E. mexicanus, is the only one gerreid species confined to freshwater habitats in the southeastern Mexico and northern Guatemala (Deckert, 1973; Deckert \& Greenfield, 1987; Castro-Aguirre et al., 1999; Miller et al., 2006).

${ }^{1}$ Colección de Peces, Departamento de Conservación de la Biodiversidad. El Colegio de la Frontera Sur, Carretera Panamericana y Periférico Sur s/n, San Cristóbal de las Casas, Chiapas, México, C.P. 29290.

${ }^{2}$ Centro Interdisciplinario de Ciencias Marinas-IPN, Av. Instituto Politécnico Nacional S/N, Col. Playa Palo de Santa Rita, La Paz, BCS, México, C.P 23090. afgonzalez@ecosur.mx, eugerres@gmail.com (AFGA); rrodiles@ecosur.mx (RRH) 
The amphiamerican genus Eugerres includes seven species with serrations on the lower margin of the preopercular and preorbital bones, a characteristic commonly used to distinguish them from other American gerreid genera (e.g., Deckert \& Greenfield, 1987; Gilmore \& Greenfield, 2002; McEachran \& Fechhelm, 2005; Miller et al., 2006). Representative species of this genus are distributed along the eastern Pacific: E. axillaris (Günther, 1864), E. brevimanus (Günther, 1864) and E. lineatus (Humboldt, 1821); in the western Atlantic: E. awlae (Schultz, 1949), E. brasilianus (Cuvier, 1830) and E. plumieri (Cuvier, 1830); and in the Coatzacoalcos, Grijalva and río Usumacinta basins in the highlands of southeastern Mexico and northern Guatemala, the vicarious E. mexicanus (Steindachner, 1863) (González-Acosta et al., 2005, 2007).

González-Acosta (2005) and González-Acosta et al. (2005, 2007) have identified phenotypic differences between 'marineestuarine' and 'freshwater' gerreids based on morphological and meristic studies. A taxonomic review of the Mexican mojarra (E. mexicanus) permitted us to identify a differentiated morph from the ríos Grijalva-Usumacinta basin in southeastern Mexico and northern Guatemala which are described here as Eugerres castroaguirrei new species.

\section{Material and Methods}

Institutional abbreviations follow Sabaj Pérez (2012) with the addition of CIDOAX for the Centro Interdisciplinario de Investigación para el Desarrollo Integral Regional - Instituto Politécnico Nacional, Unidad Oaxaca, Oaxaca, México. Specimens of the new species were critically compared with "Gerre" mexicanus syntypes [sic] NMW 72289 and NMW 78820 and those of the nominal E. mexicanus [s.l.] (see material examined section), based on the original descriptions (Steindachner, 1863), comparative examinations, and the taxonomic keys presented by Álvarez del Villar (1950, 1970), Deckert \& Greenfield (1987), Castro-Aguirre et al. (1999), Miller et al. (2006), and González-Acosta et al. (2007).

A comparative examination on the skeleton of the freshwater gerreids was conducted to identify the most distinctive bone characters between the species, the examined specimens were prepared by cleared-stained techniques following the procedure of Taylor \& van Dyke (1985), and preparing fish skeletons based on Burns \& Everly (2000). The results are presented following the body skeleton organization and the bony nomenclature of Rojo (1991), González-Acosta (2005) and Becker et al. (2009).

Twenty one linear measurements between external landmark pairs were taken with dial calipers to the nearest 0.1 $\mathrm{mm}$ from 157 specimens [125 of E. mexicanus and 42 of $E$. castroaguirrei] (Fig. 1). In this analysis, we followed in general the meristic and morphometric methods presented by Hubbs \& Lagler (1964) with additions by González-Acosta (2005). Other measurements not included in the Figure 1: interorbital length, third anal spine length, third dorsal spine length, distance between the tips of the second dorsal, and standard length (SL) were also considered.

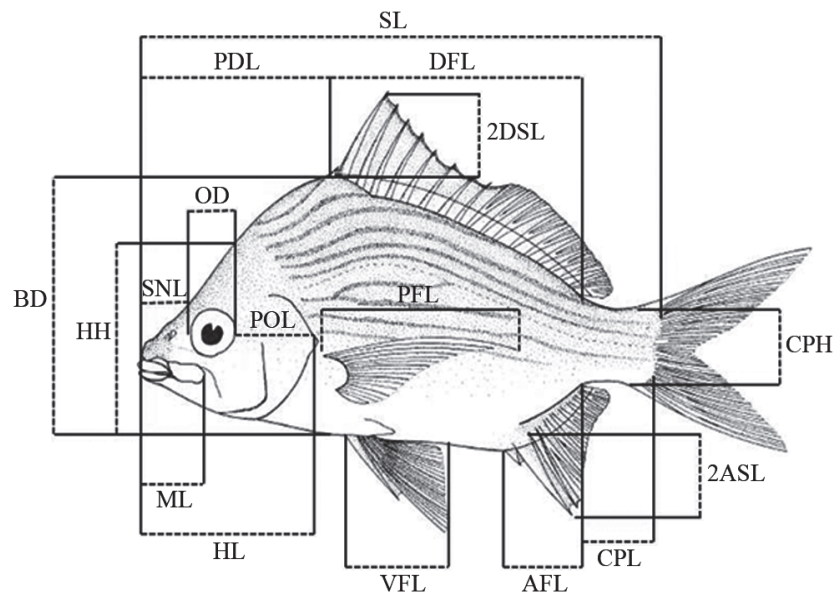

Fig. 1. Body measurements of external morphology used in morphometrics and principal component analysis: anal fin length (AFL); base of dorsal fin length (DFL); body depth (BD); caudal peduncle height $(\mathrm{CPH})$; caudal peduncle length $(\mathrm{CPL})$; head height $(\mathrm{HH})$; head length (HL); maxillary length (ML); orbit diameter (OD); pectoral fin length (PFL); postorbital length (POL); predorsal length (PDL); standard length (SL); second anal spine length (2ASL); second dorsal spine length (2DSL); snout length (SNL); ventral fin length (VFL). Measurements based on González-Acosta (2005). Drawing modified from Bussing (1995). Not included in the illustration: inter-orbital length, third anal spine length, third dorsal spine length and distance between the tips of the second dorsal and second anal spines (SL).

A Student's t-test was used to compare the means of the morphometric proportions. Principal component analysis [PC] was used to examine the variation in morphometric proportions to eliminate the effects of size. The PC analysis was performed on a correlation matrix of log-transformed data, using 20 body measurements (excluding SL) from the external morphology of each specimen. All morphometric data were standardized to remove the size component from the shape measurements and to minimize bias due to variability in standard length, according to Elliot et al. (1995). Likewise, measurements were log-transformed to homogenize the variances (Sokal \& Rohlf, 1981). Diagnoses and descriptions are given for the taxa included.

\section{Results}

In their critical studies of the genus Eugerres, Deckert (1973) and Deckert \& Greenfield (1987) did not identify meristic or morphometric variations among populations of ' $E$. mexicanus' [s.l.] from Mexico and Guatemala; they identified to 'E. mexicanus' $[$ s.l.] as the only New World gerreid restricted to freshwater. Recently, González-Acosta (2005) and GonzálezAcosta et al. (2007) identified an additional morph (E. aff. mexicanus) based on an examination of E. mexicanus [s.s.] 
specimens (including type materials) from several localities in their known range of distribution.

Taxonomic analyses conducted on 'Gerres' mexicanus syntypes [sic] NMW 72289 (165.6 mm SL) and NMW 78820 (142.8-152.5 mm SL) allowed us confirm the identity of Eugerres mexicanus (sensu Steindachner, 1863) and distinguish it from the E. aff. mexicanus morph included in the 'E. mexicanus' [s.l.] complex (González-Acosta et al., 2007), and described herein as E. castroaguirrei new species. As well as, morphometric comparisons permit differentiation of two forms as distinct species (Tables 1-2). Thus, $E$. mexicanus can be distinguished by the length of the second dorsal and anal fin spines in relation to the standard and head lengths (Fig. 2a), respectively. Likewise, the depressed second dorsal-fin spine reaches the base of the fifth or sixth dorsalfin rays and the second anal-fin spine, when depressed extends to distal the point of the last anal-fin ray.

Freshwater species were morphologically different. Proportional measurements (Tables 1-2) indicate that Eugerres castroaguirrei, has a moderate orbit diameter and second dorsal and anal spine length; and a longer head, snout, and postorbital length. Thus, the new species differs from $E$. mexicanus, except in terms SL-body depths ratio (Tables 1-2).

Based on the results of the principal components analysis of 20 morphometric variables (excluding SL), the distinction between Eugerres mexicanus and E. castroaguirrei is largely described by PC-I $v$ s. PC-II (Fig. 2b). The variables that loaded most heavily on PC-I ( $<50 \%$ of the variance $)$ included: body depth, length of dorsal and anal fin bases, postorbital length, head length, interorbital length, head height, pelvic fin length, caudal peduncle height and length, upper jaw length, and snout length (Table 3 ). Those that loaded most heavily on
PC-II included: length of second dorsal and anal-fin spines, and length of third dorsal and anal-fin spines (Table 3).

\section{Eugerres castroaguirrei, new species}

(Fig. 3a)

Diapterus mexicanus (not of Steindachner). Chávez Lomelí et al., 1989: 89 (description). Rodiles- Hernández et al., 1999: 460 (list; distribution) [in part et non] Gerres mexicanus Steindachner, 1863.

Eugerres mexicanus (not of Steindachner). RodilesHernández, 2005: 204 (list; distribution; ecological notes) [in part et non] Gerres mexicanus Steindachner, 1863.

Holotype. ECOSC 775, 184.3 mm SL, México, Chiapas, Marqués de Comillas, Lacandona Rainforest, río Lacantún, between Reforma Agraria and Galaxia, 16 ${ }^{\circ} 14 ' 35^{\prime}$ N 90 51'30'W, 25 Mar 1997, R. Rodiles-Hernández.

Paratypes. All collected with the holotype: AMNH 239190, 1, 221.6 mm SL; UABC 2665, 1, 226.3 mm SL; FMNH 117268, 1, 228.5 mm SL; IBUNAM 11436, 1, 213 mm SL; NMW 95100, 1, $202.1 \mathrm{~mm}$ SL; and UMMZ 247665, 1, $194.3 \mathrm{~mm}$ SL.

Diagnosis. Eugerres castroaguirrei is distinct from its congeners (except E. mexicanus) by their body oblong and laterally ticker ( $v s$. deep and laterally compressed) and the dorsal-fin origin posterior to the insertion of the pectoral and pelvic fins ( $v s$. anterior to the insertion of the pectoral and pelvic fins). Differs from E. mexicanus by the combination of the following characteristics: length of second dorsal-fin spine $23.2-34.2 \%$ SL (vs. 18.9-43.3\% SL); depressed second dorsal-spine extends to base of third or

Table 1. Morphometric data for Holotype, six Paratypes, and 35 non-type specimens of Eugerres castroaguirrei. Standard length, body depth and head length are expressed in millimeters. Numbers in parentheses: mean; SD: Standard deviation.

\begin{tabular}{|c|c|c|c|c|c|}
\hline Eugerres castroaguirrei new species & Holotype & Paratypes & SD & non-type specimens & SD \\
\hline Standard length & 184.3 & $194.3-228.5(214.3)$ & 13.7 & $141.6-241.7(204.4)$ & 21.2 \\
\hline Body depth & 69.8 & $72.8-84.2(79.4)$ & 5.1 & $50.8-89.8(76.6)$ & 7.3 \\
\hline Head length & 60.6 & $63.2-78.8(71.0)$ & 5.4 & $47.3-84.7(66.9)$ & 7.8 \\
\hline \multicolumn{6}{|c|}{ In percent of standard length } \\
\hline 1. Body depth & 37.9 & $36.0-38.3(37.0)$ & 0.8 & $33.8-42.1(37.5)$ & 1.6 \\
\hline 2. Distance between the tips of the second dorsal and second anal spines & 68.3 & $57.5-71.1(64.4)$ & 5.8 & $55.4-75.4(65.6)$ & 4.8 \\
\hline 3. Head length & 32.8 & $31.4-34.8(33.1)$ & 1.1 & $28.2-38.2(32.7)$ & 1.8 \\
\hline 4. Second dorsal spine length & 31.1 & $23.3-29.1(26.1)$ & 2.1 & $23.2-34.2(28.0)$ & 2.9 \\
\hline 5. Second anal spine length & 17.8 & $12.7-17.4(15.2)$ & 1.6 & $11.1-20.6(16.4)$ & 1.7 \\
\hline \multicolumn{6}{|c|}{ In percent of body depth } \\
\hline 6. Second dorsal spine length & 82.0 & $63.3-81.0(70.6)$ & 6.3 & $62.4-88.3(74.6)$ & 7.1 \\
\hline 7. Second anal spine length & 45.1 & $34.4-48.5(41.0)$ & 4.6 & $28.0-57.4(43.7)$ & 4.5 \\
\hline \multicolumn{6}{|c|}{ In percent of head length } \\
\hline 8. Second dorsal spine length & 94.6 & $69.4-87.9(79.0)$ & 6.7 & $69.5-109.3(85.7)$ & 9.9 \\
\hline 9. Second anal length & 52.0 & $40.3-52.7(45.8)$ & 4.7 & $35.1-61.7(50.1)$ & 5.2 \\
\hline 10. Orbit diameter & 27.2 & $24.0-29.6(27.1)$ & 2.2 & $23.3-31.5(27.3)$ & 1.9 \\
\hline 11. Snout length & 38.2 & $34.0-38.2(35.8)$ & 1.6 & $33.7-50.1(38.7)$ & 3.8 \\
\hline 12. Postorbital length & 40.3 & $40.3-44.3(42.3)$ & 1.5 & $38.1-45.8(41.9)$ & 1.6 \\
\hline \multicolumn{6}{|c|}{ Other body proportions } \\
\hline 13. Second anal spine length in & 84.4 & 73.7-101.9 (90.3) & 9.3 & $67.3-121.9(95.7)$ & 9.8 \\
\hline 14. Second anal spine length in caudal peduncle length & 85.2 & $64.1-90.8(79.2)$ & 9.8 & $55.5-111.9(91.9)$ & 10.8 \\
\hline 15. Second anal spine length in second dorsal spine length & 55.0 & $54.0-61.6(58.0)$ & 3.1 & $37.3-74.9(58.8)$ & 6.0 \\
\hline
\end{tabular}


Table 2. Morphometric data for Lectotype, two Paratypes, and 122 non-type specimens of Eugerres mexicanus. Standard length, body depth and head length are expressed in millimeters. Numbers in parentheses: mean; SD: Standard deviation.

\begin{tabular}{|c|c|c|c|c|c|}
\hline Eugerres mexicanus & Lectotype & Paralectotypes & $\mathrm{SD}$ & Non-type specimens & SD \\
\hline Standard length & 165.7 & $142.8-152.5(147.6)$ & 6.8 & $43.7-193.0(125.9)$ & 39.8 \\
\hline Head length & 50.2 & $40.6-44.0(42.3)$ & 2.4 & $14.1-67.7(40.4)$ & 13.3 \\
\hline \multicolumn{6}{|c|}{ In percent of standard length } \\
\hline 2. Distance between the tips of the second dorsal and second anal spines & 87.6 & $87.9-88.2(88.0)$ & 0.2 & $63.3-102.1(81.1)$ & 8.2 \\
\hline 3. Head length & 30.3 & $28.4-28.8(28.6)$ & 0.3 & $27.7-36.4(32.0)$ & 1.6 \\
\hline 4. Second dorsal spine length & 36.9 & 31.8-34.7 (33.2) & 2.0 & $18.9-43.3(35.5)$ & 3.9 \\
\hline 6. Second dorsal spine length & 91.4 & 80.6-92.7 (86.6) & 8.5 & $51.0-118.6(94.3)$ & 9.6 \\
\hline 7. Second anal spine length & 52.9 & $50.7-56.7(53.7)$ & 4.2 & 44.6-84.2 (59.2) & 7.1 \\
\hline \multicolumn{6}{|c|}{ In percent of head length } \\
\hline 8. Second dorsal spine length & 122.1 & $110.2-122.0(116.1)$ & 8.3 & 55.4-144.7 (111.3) & 14.1 \\
\hline 9. Second anal length & 70.7 & 69.2-74.7 (71.9) & 3.9 & $47.8-89.3(69.7)$ & 8.2 \\
\hline 10. Orbit diameter & 32.6 & $33.0-35.5(34.3)$ & 1.7 & $26.5-46.3(34.2)$ & 3.9 \\
\hline 15. Second anal spine length in second dorsal spine length & 57.9 & $61.2-62.8(62.0)$ & 1.1 & $51.8-107.5(63.0)$ & 6.9 \\
\hline
\end{tabular}
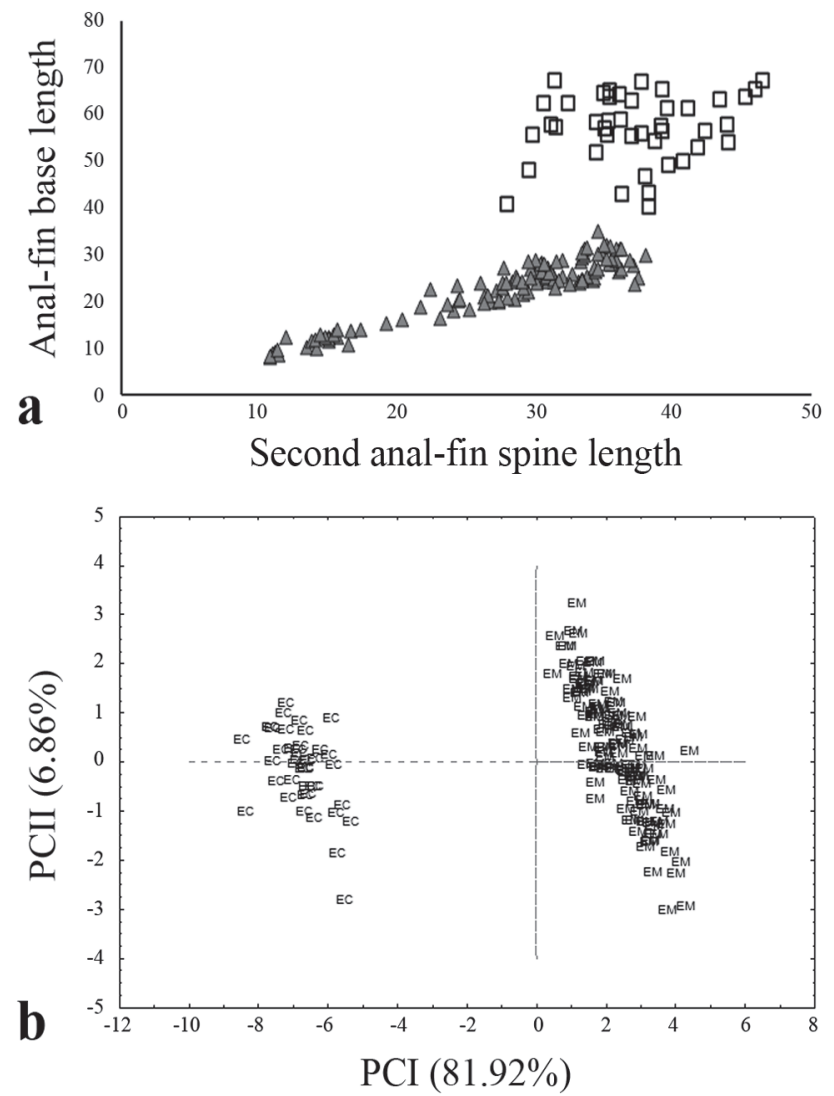

Fig. 2. a) Graphical index for discrimination of Eugerres castroaguirrei (squares, $\mathrm{n}=42$ ) and E. mexicanus (triangles, $\mathrm{n}=122$ ), provide by the biplot of second anal-fin spine length against anal-fin base. b) Plot of principal components (PC) scores for E. castroaguirrei (EC) and E. mexicanus (EM) from the southeastern of Mexico and northern Guatemala. fourth dorsal-fin rays; length of second anal-fin spine 11.1$20.6 \%$ SL ( $v s .16 .7-30.2 \%$ SL); depressed second anal-fin spine extends to base of third or fourth anal fin-rays and not reaching the distal point of last anal-fin ray; orbit diameter 23.3-31.5\% HL (vs. 26.5-45.3\% SL); pelvic-fin spine 49.7$65.0 \% \mathrm{SL}$ ( $v s .42 .3-78.2 \% \mathrm{SL}$ ) in the length of first pelvic-fin ray. Lower lips ventrally extending to midpoint of eye (vs. ventrally not reaching the anterior margin of eye).

Description. Dorsal-fin rays IX,10; anal-fin rays III,8; pectoral-fin rays iii, 12,i; pelvic-fin rays I,5; pored lateral-line (LL) scales 43-51 (mode 46); scales between base of dorsalfin and LL 3.5-4 (mode 4); scales between LL and anal-fin base 8-9 (mode 9); gill rakers on lower limb of first arch 12-15 (mode 13). Predorsal margin sharply convex. Interorbital space with a wide and central oval depression; premaxillary groove without scales. Maxillary extending to posterior margin of pupil. Dorsal fin origin inserts behind anterior margin of pectoral and pelvic fins; posterior margin of dorsal fin, nearly straight. Second dorsal-fin spine thicker than third dorsal-fin spine, but equal in length. Second anal-fin spine hooked, thicker than third and equal in length. Pectoral fins lanceolate, frequently extend past vent but not reaching the anal fin origin. Caudal-fin deeply forked, lobes equal in length (thicker than in E. mexicanus); lower lobe thicker than upper. Mouth protractile and terminal; upper and lower lips enlarged, the lower lips ventrally flattened and extending to midpoint of eye. Pharyngeal teeth granular, serially arranged. Posterior and lower preopercle margins with conspicuous serrations. Lower margins of preorbital 1 and jugal serrated. Subopercular and infraorbital margins frequently serrated. Head covered by small cycloid scales; ctenoid scales on 
Table 3. Character loading on principal components I-II for 16 measurements taken on 42 specimens of E. castroaguirrei and 125 of E. mexcanus from the Grijalva-Usumacinta River Basin. Bold values represent the variables that loaded most heavily on PC-I and PC-II.

\begin{tabular}{lcc}
\hline Morphometric features & PC I & PC II \\
\hline Standard length & & \\
Body depth & $\mathbf{0 . 0 5 8 5 7 3}$ & 0.002153 \\
Head height & $\mathbf{0 . 0 5 5 9 0 0}$ & 0.008311 \\
Snout length & $\mathbf{0 . 0 5 0 3 3 4}$ & 0.053506 \\
Orbit diameter & 0.047959 & 0.007944 \\
Postorbital length & $\mathbf{0 . 0 5 6 4 4 4}$ & 0.027117 \\
Predorsal length & 0.035646 & 0.018372 \\
Distance between the tips of the second dorsal and second anal spines & 0.044780 & 0.046350 \\
Length of dorsal-fin base & $\mathbf{0 . 0 5 8 2 6 9}$ & 0.006356 \\
Second dorsal spine length & 0.037710 & $\mathbf{0 . 1 8 8 8 1 7}$ \\
Third dorsal spine length & 0.041736 & $\mathbf{0 . 1 6 9 5 9 5}$ \\
Caudal peduncle height & $\mathbf{0 . 0 5 4 2 4 4}$ & 0.005066 \\
Second anal spine length & 0.035201 & $\mathbf{0 . 2 1 2 9 4 1}$ \\
Third anal spine length & 0.041125 & $\mathbf{0 . 1 4 8 2 8 6}$ \\
Caudal peduncle length & $\mathbf{0 . 0 5 2 0 4 2}$ & 0.016911 \\
Length of anal-fin base & $\mathbf{0 . 0 5 6 0 8 6}$ & 0.002476 \\
Pelvic-fin length & $\mathbf{0 . 0 5 5 0 6 4}$ & 0.000120 \\
Pectoral-fin length & 0.051203 & 0.004267 \\
Head length & $\mathbf{0 . 0 5 6 8 9 8}$ & 0.027840 \\
Upper jaw length & $\mathbf{0 . 0 5 4 3 6 9}$ & 0.037072 \\
Interorbital length & $\mathbf{0 . 0 5 6 4 1 8}$ & 0.016499 \\
\hline
\end{tabular}

trunk. Morphometric and meristic data are presented in Tables 1 and 4, respectively.

Coloration. Coloration in life specimens yellowish-silver; four dark, wide stripes on sides; lower dark stripes discontinuous (vs. 9-11 continuous dark stripes in other Eugerres species); dorsal and caudal fins with blackish margins; pectoral, pelvic and anal fins yellowish-white. Ground color on preserved specimens silvery brown back; four well-defined longitudinal dark stripes on sides of the body; belly silver to yellowish-white; ventral stripes not well-defined; fins yellowish to brownish-white; black margin on first dorsal fin.

Size. Largest specimen examined $242.0 \mathrm{~mm} \mathrm{SL}, 312.2 \mathrm{~mm}$ TL, and weight $347.0 \mathrm{~g}$ (ECOSC 1742).

\section{Sexual dimorphism. Not observed.}

Distribution and habitat. Eugerres castroaguirrei inhabits the ríos Grijalva-Usumacinta basin in the highlands of Chiapas and Tabasco, Mexico and northern Guatemala (Fig. 4). This species has a sympatric distribution with its congener E. mexicanus.

Ecological notes. Eugerres castroaguirrei has not yet been studied; thus, biological and ecological data are lacking. Specimens of the new species are fished by local communities and consumed as food. Further studies are necessary to obtain additional data. The holotype was captured using a seine net $90 \mathrm{~cm}$ bellow surface in channel with sandy-slime bottom, $\mathrm{pH} 8.0$, conductivity $478 \mu \mathrm{S} / \mathrm{cm}$, dissolved solids 242 $\mathrm{mg} / \mathrm{l}$, dissolved oxygen $6.9 \mathrm{mg} / 1$, and $26^{\circ} \mathrm{C}$.
Etymology. The name proposed (castroaguirrei) honors the late Dr. José Luis Castro Aguirre, who made several important contributions to our understanding of Mexican fish fauna.

Proposed common name. The proposed English common name is "Lacandon mojarra", after its principal area of distribution. The proposed Spanish common name is "mojarra lacandona".

Remarks. Here we establish that Eugerres castroaguirrei was a previously overlooked species in the literature on the Family Gerreidae and freshwater ichthyofauna of Central America (e.g., Meek \& Hildebrand, 1925; Jordan \& Evermann, 1927; Deckert \& Greenfield, 1987; Castro-Aguirre et al., 1999; Miller et al., 2006). The distinctive characters of the new species are based on meristic, morphometric, and osteological analyses (see formal descriptions), comparison of the external morphology with 'Gerres' mexicanus syntypes [sic] (NMW 72289 [165.6 mm SL] and NMW 78820 [142.8-152.5 mm SL]), and specimens assigned to the nominal species (see material examined section).

Material examined. México: Chiapas, La Venta-Mal Paso, ECOSC 4560, 1, 171.0 mm SL. Tabasco-Chiapas, río Tulijá, ECOSC 4372, 1, $187.4 \mathrm{~mm}$ SL. México (Chiapas) and Guatemala, arroyo Negro, ECOSC 1570, 1, 231.6 mm SL. Río Lacanjá-Lacandona Rainforest, ECOSC 641, 1, 203.5 mm SL; ECOSC 694, 1, 199.7 mm SL; ECOSC 704, 2, 141.6-237.4 mm SL; ECOSC 1272, 1, 179.2 mm SL; ECOSC 1411, 1, $220.4 \mathrm{~mm}$ SL; ECOSC 1490, 1, 223.6 mm SL. Río Tzendales - río San Pedro mouth, ECOSC 1848, 3, 192.8-223.9 mm SL. Arroyo Cantabal, mouth of río Chixoy, UMMZ 189974, 1, $202.1 \mathrm{~mm}$ SL. Reforma Agraria - río Lacantún, ECOSC 110, 2, 188.2-219.5 mm SL. Arroyo El Bravo - río Lacantún, ECOSC 689, 1, 193.7 mm SL. Arroyo El Salado - río Lacantún, ECOSC 2191, 1, 184.6 mm SL. Playón La Gloria - río Lacantún, ECOSC 750, 3, 184.5- 
201.9 mm SL. Galaxia - río Lacantún, ECOSC 775, 6, 184.3228.5 mm SL. Boca Chajul - río Lacantún, ECOSC 1658, 1, 204.2 mm SL; ECOSC 2347, 1, 233.5 mm SL. López Mateos río Lacantún, ECOSC 1687, 2, 215.8-227.3 mm SL. Playón de la Mula - río Lacantún, ECOSC 1418, 1, 204.3 mm SL; ECOSC 1840, 2, 199.1-222.9 mm SL; ECOSC 2503, 1, 215.0 mm SL. Playón 21 - río Lacantún, ECOSC 2326, 1, 214.1 mm SL. Playa Chavín - río Lacantún, ECOSC 1742, 1, 241.7 mm SL; ECOSC 2170, 1, 181.8 mm SL. El Tigre-Boca Lacantún, ECOSC 1749, 1, 203.3 mm SL. Boca Chajulillo - río Lacantún, ECOSC 2606, 2, 167-195.1 mm SL.

\section{Eugerres mexicanus (Steindachner, 1863)}

(Fig. 3b)

Gerres mexicanus Steindachner, 1863: 383 (original description; type locality: Flus [River] Teapa, Tabasco, México).

Diapterus mexicanus (Steindachner). Meek \& Hildebrand, 1925: 592, 599 (new combination). Velasco Colín, 1976:124125 (description; distribution; figure). Gaspar-Dillanes, 1996: 46 (list; distribution). Rodiles-Hernández et al., 1999:

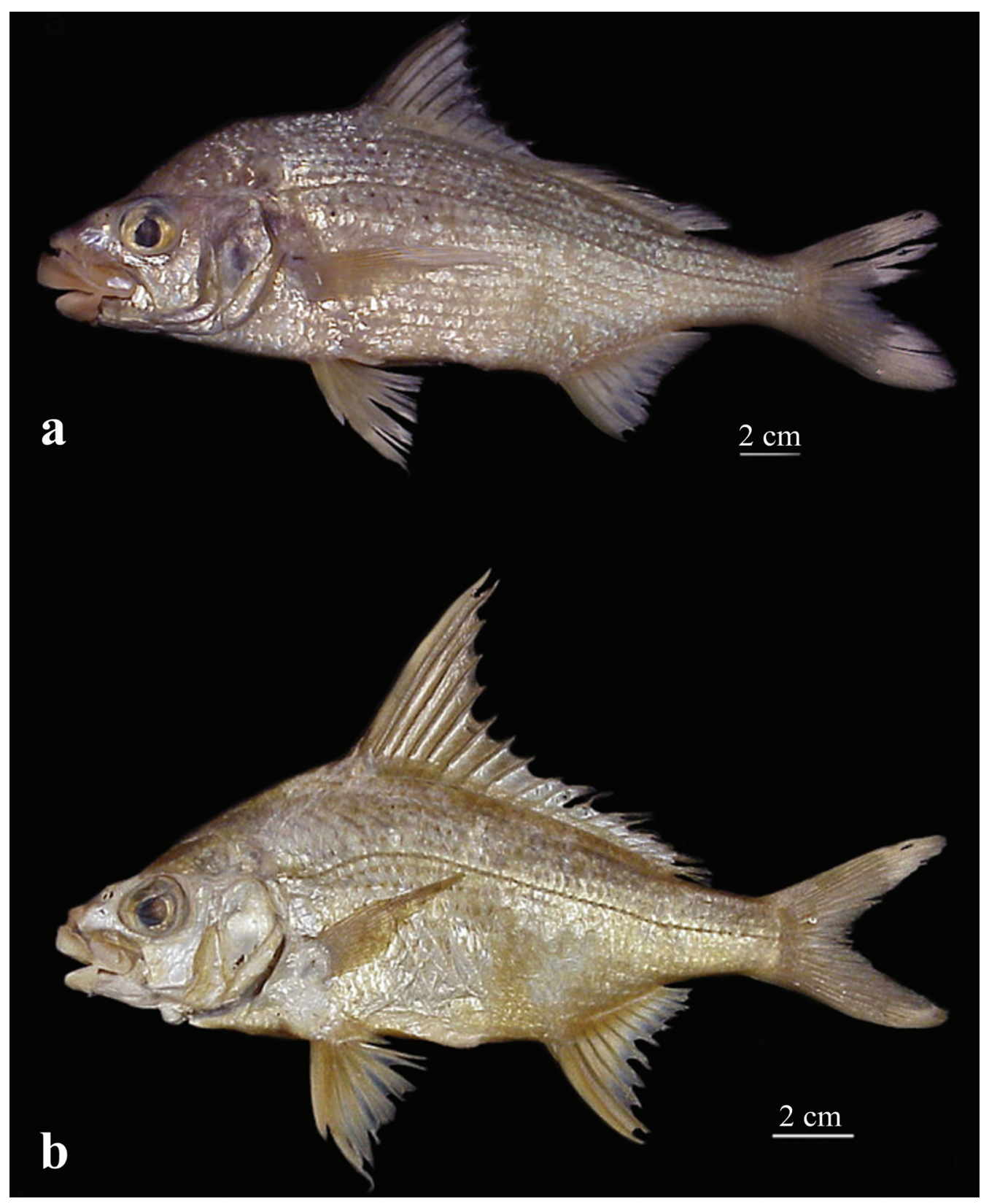

Fig. 3. a) Eugerres castroaguirrei new species, ECOSC 775, holotype, $184.3 \mathrm{~mm}$ SL. México, Chiapas, río Lacantún, Selva Lacandona, Marqués de Comillas, Reforma Agraria and Galaxia; b) Eugerres mexicanus, NMW 72289, lectotype, 165.6 mm SL. México, Tabasco, Flus (río) Teapa. 
Table 4. Frequency distribution of meristic features of Eugerres castroaguirrei and E. mexicanus from the Grijalva-Usumacinta River Basin.

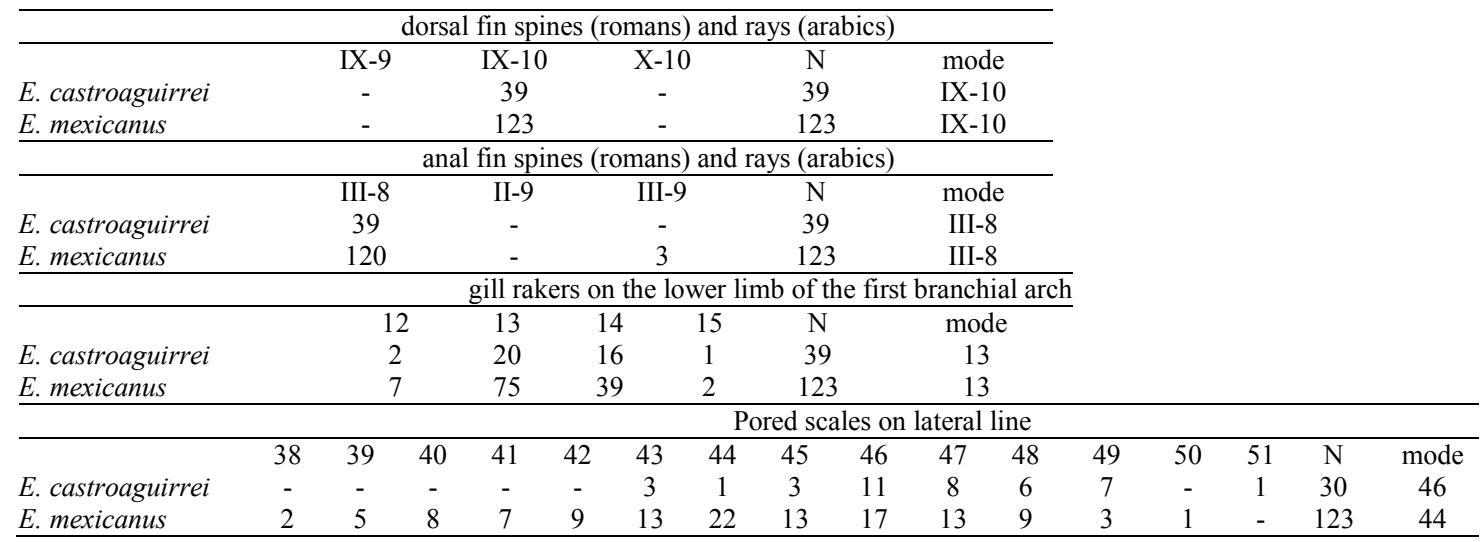

460 (list; distribution ) [in part et non] Gerres mexicanus Steindachner, 1863.

Diapterus lineatus (Humboldt). Andreata, 1988: 67 (synon.) [non] Smaris lineatus Humboldt, 1821.

Eugerres mexicanus (Steindachner). Jordan \& Evermann, 1927: 506 (new combination). Deckert, 1973: 35-36, 49-52 (key; distribution; description; figure). Deckert \& Greenfield, 1987: 189, 192-193 (key; description; figure). Rodiles-Hernández, 2005: 204 (list; distr.; ecol. notes) [in part et non] Gerres mexicanus Steindachner, 1863.
Diagnosis. Eugerres mexicanus is distinct from their marine estuarine congeners by their body oblong and laterally thicker and the dorsal-fin origin posterior to the insertion of the pectoral and pelvic fins; form its freshwater congener can be distinguished based on the combination of the following characteristics: length of second dorsal-fin spine 18.9-43.3\% SL (vs. 23.3-34.2\% SL); depressed second dorsal-fin spine extends to base of fifth or sixth dorsal-fin rays; length of second anal-fin spine 16.7-30.2\% SL (vs. 11.1-20.6\% SL); depressed second anal-fin spine extends to distal point of

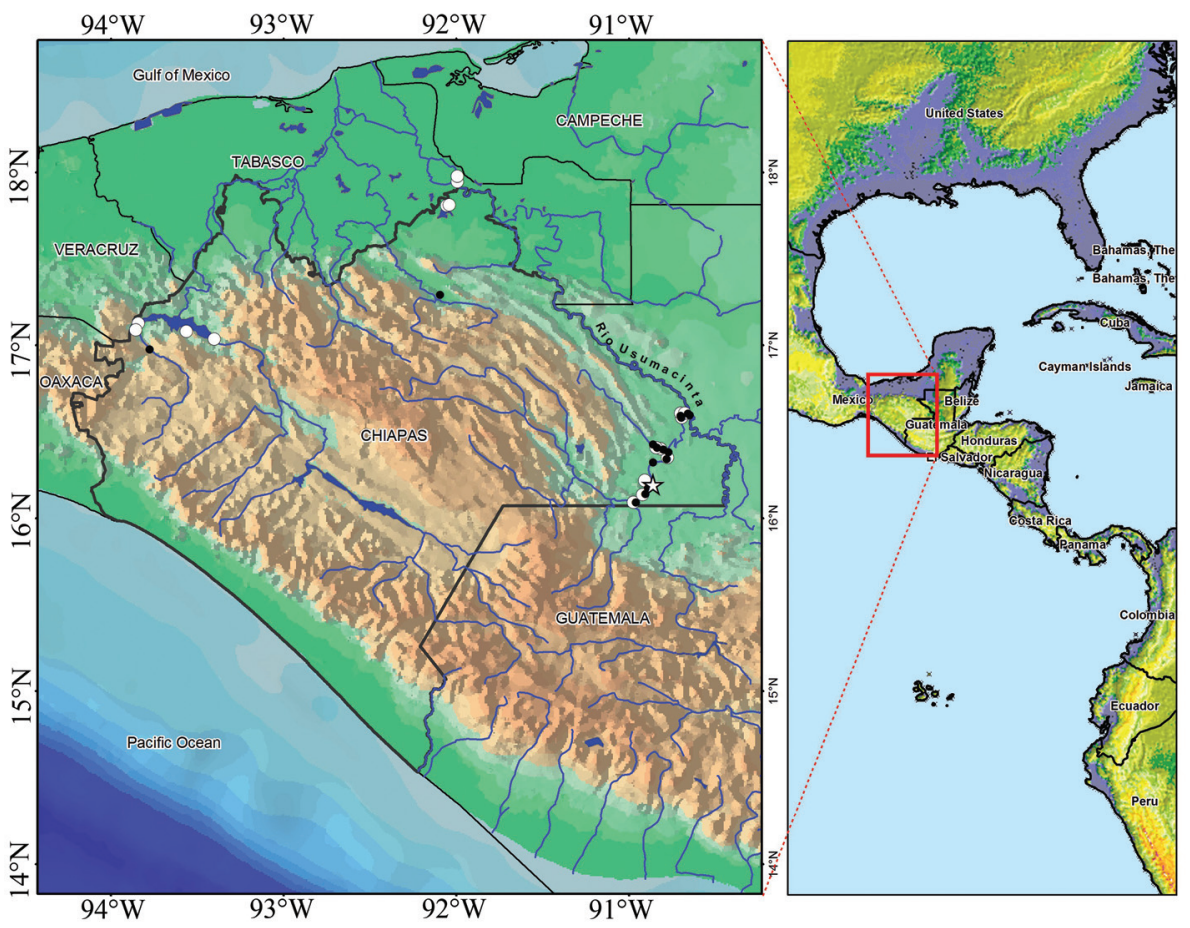

Fig. 4. Distribution of freshwater species of Eugerres in drainages along southeastern Mexico and northern Guatemala: E. castroaguirrei new species (black dots) and E. mexicanus (white dots), type locality (star). 
last anal-fin ray; orbit diameter 26.5-46.3\% HL ( $v s .23 .3-31.5 \%$ SL); pelvic-fin spine length 42.3-78.2\% SL (vs. 49.7-65.0\% SL) in the length of first pelvic-fin ray. Lower lips ventrally not reaching the anterior margin of eye ( $v s$. ventrally extending to midpoint of eye).

Description. Dorsal-fin rays IX,10; anal-fin rays III,8 (occasionally III,9; see Table 4); pectoral-fin rays iii,12,i; pelvicfin rays I,5; pored lateral-line (LL) scales 38-50 (mode 44); scales between base of dorsal fin and LL 3.5-4 (mode 4); scales between LL and anal-fin base 8-9 (mode 9); gill rakers on lower limb of first arch 12-15 (mode 13). Predorsal margin, from snout tip to dorsal-fin origin, gently convex. Interorbital space with slender, central oval depression; premaxillary groove without scales. Maxillary extending to anterior margin of pupil. Dorsal fin origin inserts behind insertion of the pectoral and pelvic fins; posterior margin of dorsal fin, concave. Second dorsal fin spine, thicker than third dorsal spine but equal in length, or a little longer when depressed. Second anal-fin spine thicker, nearly straight (not hooked) and equal in length to third anal-fin spine. Pectoral fins lanceolate, frequently reaching anal fin origin. Caudal-fin deeply forked, lobes equal in length, lower lobe thicker than upper. Mouth protractile and terminal; upper and lower lips enlarged, the lower lips ventrally flattened but not reaching the anterior margin of eye. Pharyngeal teeth granular, irregularly arranged. Posterior and lower preopercle margins with conspicuous serrations. Lower margins of preorbital 1 and jugal serrated. Subopercular and infraorbital margins frequently serrated. Head with small cycloid scales, and with ctenoid scales on rest of body. Morphometric and meristic data are presented in Tables 2 and 4, respectively.

Coloration. Coloration in life based on 26 specimens obtained from Tenosique, Tabasco, México (UABC 2666; MNHN 20060767; NMW 95101): body silvery white, brown on back; four dark, thicker stripes on sides; lower stripes dark with irregular pattern; dorsal and caudal fins blackish-white; black margin on first dorsal fin; pectoral, pelvic, and anal fins yellowishwhite. Ground color of preserved specimens silvery-black or brown; lateral dark stripes gently convex (sometimes indistinct); belly silvery to yellowish-white; ventral stripes not well-defined; fins yellowish to brownish-white; spinous portion of dorsal fin with black margin.

Size. Maximum size $300.0 \mathrm{~mm}$ SL, weight 300.0 to $400.0 \mathrm{~g}$ (Velasco Colín, 1976: 125).

\section{Sexual dimorphism. Not observed.}

Distribution and habitat. Inhabit freshwater habitats along the ríos Grijalva-Usumacinta, and Coatzacoalcos basins in southeastern México (Chiapas, Tabasco, and Veracruz) and northern Guatemala (Fig. 4). Eugerres mexicanus is endemic to the Neotropical region and the Usumacinta Province (Miller, 1966, 1982, 1986; Miller \& Smith, 1986; Miller et al., 2006), with a noteworthy distribution in highlands with elevations of 100 to $300 \mathrm{~m}$ (Castro-Aguirre et al., 1999); some of these localities are in Chiapas and the northern part of Guatemala (upper Usumacinta).

Ecological notes. Eugerres mexicanus has not been wellstudied. However, Collette \& Russo (1981) established that 'E. mexicanus' [s.l.] specimens are eaten by Batrachoides goldmani Evermann \& Goldsborough, 1902, a species with a similar distribution. The Mexican mojarra has omnivorous feeding habits, involving the consumption of insects, plants, crustaceans, and mollusks; and reach sexual maturity at 160.0 mm SL (González-Acosta, 2005). Helminthes parasites of this species had been recently reported (Salgado-Maldonado, 2006). The species is caught abundantly by local fishermen with danger of becoming overexploited. Further studies are necessary to evaluate the potential for aquaculture of this species (González-Acosta, 2005). Additional biological data for this freshwater fish are also necessary.

Common names. Eugerres mexicanus is commonly known in English as Mexican mojarra or White mojarra; in Spanish as mojarra mexicana or mojarra blanca; and along the GrijalvaUsumacinta basin as Pichincha.

Remarks. In their critical studies of the genus Eugerres, Deckert (1973) and Deckert \& Greenfield (1987) did not identify meristic or morphometric variations among populations of 'E. mexicanus' [s.l.] from Mexico and Guatemala; they determined to the White mojarra as the only New World gerreid restricted to freshwater. Recently, González-Acosta (2005) and González-Acosta et al. (2007) had identified an additional morph (E. aff. mexicanus) based on an examination of $E$. mexicanus [s.s.] specimens (including type materials) from several localities in their known range of distribution.

Also, Deckert (1973: 51) and Deckert \& Greenfield (1987: 192) cited the specimen NMF 72287 [sic] as the holotype of 'Gerres' mexicanus. According to the authors this acronym pertains to the Naturhistorisches Museum Fischsammlung. However, NMW staff members have noted that this name and acronym were never employed for the Naturhistorisches Museum Wien [NMW], the name used since 1918 (HerzigStrachil, 1997: 106). We also confirmed that specimen NMW $72287,86.3 \mathrm{~mm}$ SL, corresponds to 'Gerres' (Eucinostomus) melanopterus Bleeker, 1863 from Fernando Po, Western Africa.

In order to clarify the current status of the of E. mexicanus type specimens, we followed ICZN (1999) guidelines for namedbearing types (Arts. 72.1.1, 72.3, and 74.1), to invalidate Deckert (1973), and Deckert \& Greenfield's (1987) designation of the NMW 722897 specimen as the holotype 'Gerres' mexicanus. In addition, the lectotypes (NMW 72289 and NMW 78820) mentioned by Andreata $(1988: 69,71)$ are invalidated because the designation does not follow the ICZN guidelines. Based on our critical review of the ' $G$ ' mexicanus syntypes [sic], we designate a lectotype (NMW 72289, $165.6 \mathrm{~mm} \mathrm{SL}$ ) and two paralectotypes (NMW 78820, 142.8-152.5 mm SL) of E. mexicanus. 
Material examined: Eugerres mexicanus (Steindachner), Lectotype [designated herein] NMW 72289, $165.6 \mathrm{~mm}$ SL (new combination); México, Tabasco, Flus [River] Teapa, 1 Jan 1849, C. Heller. Paralectotypes [designated herein] NMW 78820, 2, 142.8$152.5 \mathrm{~mm} \mathrm{SL}$, same data as lectotype. México, Chiapas, Raudales de Mal Paso, ENCB 2523, 1, 121.6 mm SL. Río Mezcalapa, IBUNAM 11713, 3, 43.7-146.2 mm SL. Río La Venta-Presa Mal Paso, ECOSC 47, 3, 182.5-185.3 mm SL; ECOSC 48, 2, 175-185.8 mm SL. Presa Mal Paso-Monte Alegre, ECOSC 303, 1, 190.8 mm SL. Presa Mal Paso-El Encajonado, ECOSC 4441, 2, 181-185.15 mm SL. México: Veracruz and Oaxaca: Río Coatzacoalcos, NMW 72290, 1, 149.4 mm SL. Río Chiquito, UMMZ 187699, 28, 17.1$35 \mathrm{~mm}$ SL. Arroyo Limones - río del robalo, CIDOAX, 154 1, 114.5 mm SL. México, Tabasco - Chiapas, Tenosique, MNHN 20060767, 2, 140.0-163.0 mm SL; NMW 95101, 2, 140.3-144.0 mm SL; UABC 2666, 14, 132.6-170.3 mm SL. Paraíso-Arroyo El Raizal, ECOSC 2394, 3, 146.1-154.6 mm SL; ECOSC 2535, 3, 140.4-157.1 mm SL; ECOSC 2850, 2, 54.4-68.3 mm SL. Laguna Catazajá-Arroyo El Raizal, ECOSC 3622, 1, 125.6 mm SL. La Libertad - río Chacamax, ECOSC 3493, 1, 145.6 mm SL. Laguna Saquilá - río Chacamax, ECOSC 3643, 1, $129.58 \mathrm{~mm}$ SL. México and Guatemala, Rio Lacanjá-Lacandona Rainforest, ECOSC 380, 1, 140.6 mm SL; ECOSC 398, 7, 140.4-170.4 mm SL; ECOSC 431, 1, 107.9 mm SL; ECOSC 704, 1, 151.1 mm SL; ECOSC 1490, 1, 139.2 mm SL. Río Tzendales-Lacandona Rainforest, ECOSC 587, 1, 180.5 mm SL. Arroyo Jimbal - río Tzendales, ECOSC 2306, 2, 135.4-193 mm SL; ECOSC 2612, 1, 153.6 mm SL. Arroyo El Bravo - río Lacantún, ECOSC 689, 1, 143.5 mm SL; ECOSC 1085, 1, 124.7 mm SL. Arroyo Caribe - río Lacantún, ECOSC 2302, 2, 93.3-105.5 mm SL; ECOSC 2310, 1, 151.5 mm SL. Río Chajulillo, ECOSC 2541, 1, 128.4 mm SL; ECOSC 1659, 1, 65.5 mm SL. Boca de Chajul - río Lacantún, ECOSC 1904, 1, 95.6 mm SL; ECOSC 2606, 1, 167.0 $\mathrm{mm}$ SL. Mouth of río Lacantún, ECOSC 1853, 2, 131.5-148.5 mm SL; ECOSC 1860, 1, 82.6 mm SL; ECOSC 2177, 3, 46.2-111.6 mm SL. Arroyo San Lorenzo-mouth of Río Lacantún, ECOSC 2629, 1, $107.3 \mathrm{~mm}$ SL. Arroyo Miranda - río Lacantún, ECOSC 2545, 2, 120.8-133.3 mm SL. Pico de Oro - río Lacantún, IBUNAM 5689, 9, 44.4-66.8 mm SL. Río San Pedro (E1 Petén, Guatemala), UMMZ 143689, 39, 97,0-149.0 mm SL. Río de la Pasión (= Río Chajmaic, Alta Verapaz), UMMZ 143690, 2, 179.8-190.1 mm SL. Arroyo Cantabal, mouth of the Río Chixoy, UMMZ 189974, 14, 82.3$147.9 \mathrm{~mm}$ SL.

Comparative material: Gerres melanopterus Bleeker, 1863, NMW 72287, 86.3 mm SL, Fernando-Po, West Africa. Col. Corv. Helgol, 18d, 1885 (sic).

\section{Osteology of freshwater gerreids}

Neurocranium. In the freshwater gerreid species the neurocranium is characterized by a triangular-shaped supraoccipital crest with an anterior process convex and with a broad base, which differs from marine estuarine species where the anterior process of the supraoccipital is right angled or straight with a narrower base (González-Acosta, 2005). The anterior process of supraccipital in E. mexicanus is nearly straight (Fig. 5a), whereas E. castroaguirrei is convex (Fig. 5b).

The parietal in E. mexicanus is bell-shaped, the epioccipital has a short rear projection, the internal crest of the frontal is reduced and the pterosphenoid thinner (Fig. 5a). Whereas in E. castroaguirrei the parietal is triangular- shaped, the epioccipital has an expanded rear projection, the internal crest of the frontal is thickened and the pterosphenoid slender (Fig. 5b).

The infraorbital 1 in E. mexicanus is trapezoidal-shaped but with the anterior margin almost straight; the ventral margin is somewhat concave and markedly serrated; the caudal process is enlarged and pointed; the dorsal apophysis is dactylar-shaped with a pointed apex; a foramen is absent (Fig. 5c). In contrast, $E$. castroaguirrei has a first infraorbital bone trapezoidal-shaped with their anterior margin rounded; the ventral margin is concave and finely serrated; the caudal process is rectangular and pointed; the dorsal apophysis is blunt; a foramen is present (Fig. 5d).

Branchiocranium. The premaxilla in E. mexicanus is slender, presents an ascending process developed with margins almost straight; the articular process is digitiform but with a wide basis, the caudal process is rounded rectangular and the symphysial process is angular and notched (Fig. 6a). In $E$. castroaguirrei the premaxilla is thickened, presents an ascending process developed with margins curved, the articular process is digitiform with a reduced base, the caudal process is markedly rectangular and the symphysial process is rounded without a notch (Fig. 6b).

Marine estuarine species of Eugerres are characterized by the presence of molariform-like teeth in the pharyngeal and pharyngobranchial plates (González-Acosta, 2005), condition that differ in freshwater species where the

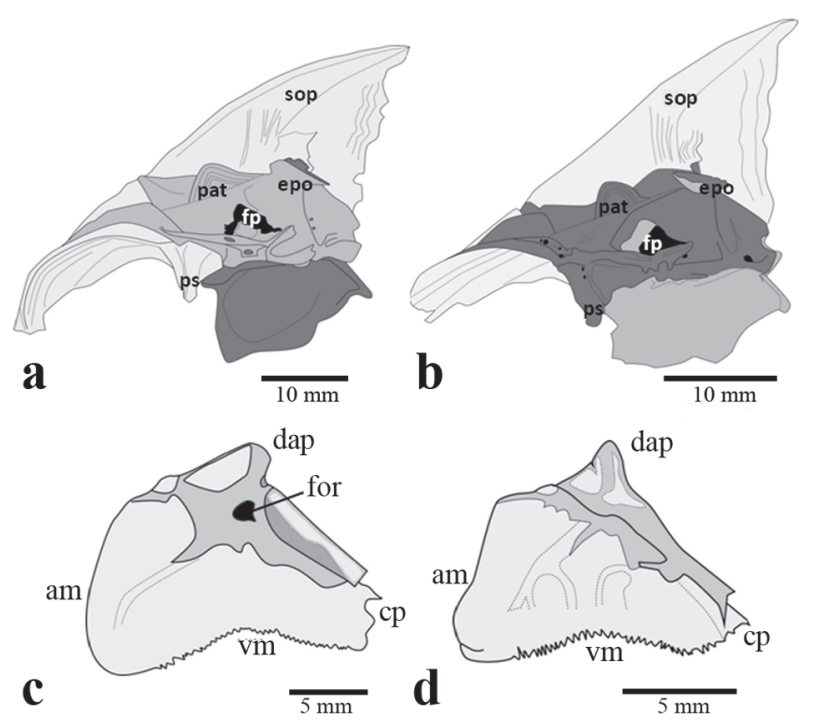

Fig. 5. Lateral view of neurocranium of (a) E. castroaguirrei, ECOSC 5511-1, and (b) E. mexicanus UABC 2666. epo = epioccipital, $\mathrm{fp}=$ foramen postemporal, $\mathrm{pat}=$ parietal, $\mathrm{ps}=$ pterosphenoid, sop $=$ supraoccipital process. Lateral view of infraorbital 1 in (c) E. castroaguirrei and (d) E. mexicanus. dap $=$ dorsal apophysis, am $=$ anterior margin, $\mathrm{cp}=$ caudal process, for $=$ foramen, $\mathrm{vm}=$ ventral margin. Both structures from left side. 
pharyngeal teeth are granular; in particular, E. mexicanus has an irregular arrangement of the dentition in the pharyngeal plates (Fig. 6c), whereas E. castroaguirrei is distinguishable by the presence of a dentition serialy arrangement in the pharyngeal plates (Fig. 6d).

Dorsal fin supports. In both freshwater species of Eugerres, the first and second dorsal-fin spines are supported by a singular pterygiophore structure, in which the first and second dorsal supports are fused and supported by a proximal radial or first pterygiophore. In E. mexicanus the first dorsal spine is small and the second spine long, equaling about $51.7 \%$ the pterygiophore length (Fig. 7a); whereas in $E$. castroaguirrei, the first dorsal spine is also small or reduced but the second spine is long, equal to about $55.5 \%$ of the pterygiophore length (Fig. 7b).

Anal fin supports. As in the dorsal fin, the first and second anal-fin spines are supported by the apparently fused first and second pterygiophores. In E. mexicanus this pterygiophore had a rounded anterior margin and their length comprising $79.4 \%$ of the second anal-fin spine length (Fig. 7c). In contrast, the pterygiophore in E. castroaguirrei has a rectangular anterior margin and their length is about $97.5 \%$ of the second anal-fin spine length, with a rectangular anterior margin (Fig. 7d).

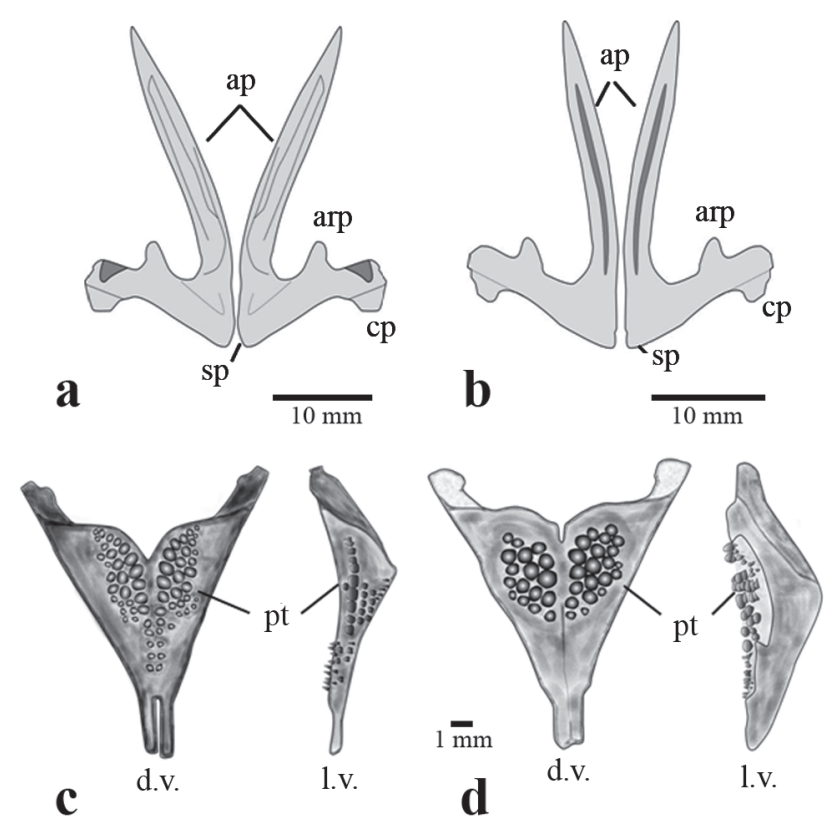

Fig. 6. Premaxillary bone, dorsal view, in (a) Eugerres castroaguirrei ECOSC 5511-1, and (b) E. mexicanus UABC 2666. ap $=$ ascending process, arp $=$ articular process, $\mathrm{cp}=$ caudal process, $\mathrm{sp}=$ symphysial process. Pharyngeal plates in (c) E. castroaguirrei and (d) E. mexicanus: dorsal view (d.v.) and lateral view (l.v.). pt $=$ pharyngeal dentition.

\section{Discussion}

The Usumacinta Province, located in the northern part of the Neotropical Region, is characterized by numerous derivatives of marine species adapted to freshwater (e.g., Batrachoides goldmani Evermann \& Goldsborough, 1902, Hyporhamphus mexicanus Álvarez, 1959 and Strongylura hubbsi Collette, 1974), with impoverished primary and secondary ichthyofauna. There are numerous low-elevation rivers and lakes along the Atlantic slope characterized by the warmer temperatures found in tropical climates (Miller, 1982). The evolutionary radiation of fish in this region indicates old ichthyofauna with a high degree of endemism at the generic and suprageneric levels (Briggs, 1994).

The discovery of new freshwater taxa is significant and could change our understanding of continental ichthyofauna (Lundberg et al., 2007). Examples of this in the area are the endemic 'Chiapas catfish' Lacantunia
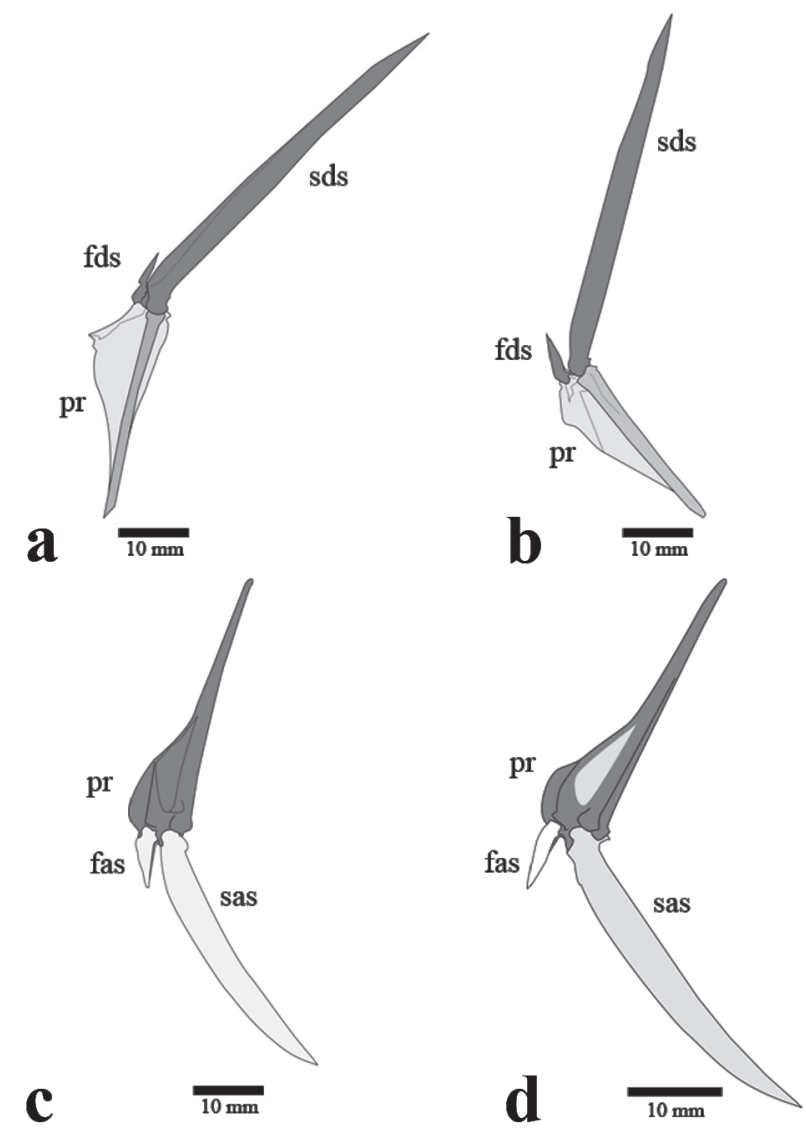

Fig. 7. Dorsal fin supports of (a) E. castroaguirrei ECOSC 5511-1, and (b) E. mexicanus UABC 2666. fds = first dorsal spine, $\mathrm{sds}=$ second dorsal spine, $\mathrm{pr}=$ proximal radial; anal fin supports of (c) E. castroaguirrei and (d) E. mexicanus. fas = first anal spine, sas $=$ second anal spine, $\mathrm{pr}=$ proximal radial. Both structures from left side. 
enigmatica Rodiles-Hernández, Hendrickson \& Lundberg, 2005, 'the mojarra from the Ocotal' Rocio ocotal SchmitterSoto, 2007, and 'Usumacinta sea catfish' Potamarius usumacintae Betancur \& Willink, 2007. Likewise, E. castroaguirrei represents a new component of Mesoamerican aquatic fauna, which are characterized by complex and elusive biogeographical and geological histories (Raven \& Axelrod, 1979; Savage, 1982). Its discovery has increased the diversity of the fish in the area. The region is negatively affected by the impact of human activities, including the introduction and invasion of exotic species, the destruction of habitats by deforestation, the impact of hydroelectric and agricultural developments on natural drainage basins (Lozano-Vilano et al., 2007).

Eugerres castroaguirrei represents the second known vicarious freshwater species of Gerreidae in the New World. The new species is locally sympatric with $E$. mexicanus and shares its distribution with representative species from other families of marine origin [Ariidae: Cathorops aguadulce (Meek, 1904), Potamarius nelsoni (Evermann \& Goldsborough, 1902) and P. usumacintae; Batrachoididae: Batrachoides goldmani; Belonidae: Strongylura hubbsi; Centropomidae: Centropomus parallelus Poey, 1860 and Hemiramphidae: Hyporhamphus mexicanus].

It has been hypothesized that vicarious species are derivatives fish with marine ancestry that migrated from their original habitat at different times (Lovejoy \& Collette, 2001). Studies of molecular characteristics should provide further information regarding genetic distinctions between $E$. castroaguirrei and their relatives, as well as the timing of the divergence of the marine estuarine and freshwater groups.

The comparative analysis based on the osteology of the species supported their taxonomic distinction on the basis of the differential morphology of some bones from several body regions: neurocranium (supraoccipital process), orbitotemporal region (parietal, epioccipital and pterosphenoid), oromandibular region (premaxilla, pharyngobranchial plates), orbital region (infraorbital 1), and the appendicular skeleton (dorsal and anal fin pterygiophores). Differences observed between the bone anatomy of the freshwater group and those reported for marine estuarine species (Andreata, 1988; Andreata \& Barbiéri, 1981; González-Acosta, 2005), support the idea to include in further studies to the freshwater gerreid species in a different taxonomic category at genus level (GonzálezAcosta et al., 2007).

\section{Acknowledgments}

This study is dedicated to the memory of the doctors José Luis Castro Aguirre and Joseph S. Nelson. We thank to Barbara Brown, Scott Schaeffer, and Damaris Rodríguez (AMNH); Francisco de Lachica Bonilla (CICIMAR-IPN); Alfonso González Díaz (ECOSUR); Héctor Espinosa Pérez and Leticia Huidobro Campos (IBUNAM); Douglas W.
Nelson (UMMZ); and Emanuel Méndez Guillermo for lending and donating specimens. AFGA is grateful to Helmut Wellendorf, Christa Prenner, Ernst Mikschi, and Barbara Herzig-Strachil (NMW) for their assistance and hospitality. Thanks to José Luis Castro Aguirre, Joseph S. Nelson, Gorgonio Ruiz Campos and to John Lundberg for their helpful comments on this manuscript, and to Chris Myroth (IDLNIU) for his assistance with the library research. The distributional map was prepared by D. M. Díaz-Bonífaz (ECOSUR). This study was partially funded by SNICONACYT (53374 and 90350), SIP-IPN (20080178 and 20121115), and NMW grants. AFGA also thanks to COFAA and EDI-IPN. Kristin Sullivan edited the English manuscript.

\section{Literature Cited}

Álvarez del Villar, J. 1950. Claves para la determinación de especies en los peces de las aguas continentales mexicanas. Secretaría de Marina, México, D.F., Dirección General de Pesca e Industrias Conexas.

Álvarez del Villar, J. 1970. Peces mexicanos (claves). México, D. F., Instituto Nacional de Investigaciones Biológico Pesqueras, Serie Investigación Pesquera.

Andreata, J. V. 1988. Revisão taxonônomica do gênero Diapterus Ranzani, 1840 (Pisces, Perciformes, Gerreidae). Acta Biologica Leopoldensia, 10: 59-103.

Andreata, J. V. \& L. L. R. Barbiéri. 1981. Osteologia do crânio de Diapterus brasilianus (Cuvier, 1830) (Perciformes,Percoidei, Gerreidae). Revista Brasileira de Biologia, 41: 565-574.

Becker, M. A., J. A. Chamberlain, Jr., J. G. Lundberg, W. J. L'Amoreaux, R. B. Chamberlain \& T. M. Holden. 2009. Beryciform-like fish fossils (Teleostei: Acanthomorpha: Euacanthopterygii) from the late Cretaceous - early Tertiary of NewJersey. Proceedings of the Academy of Natural Sciences of Philadelphia, 158: 159-181.

Briggs, J. C. 1994. The genesis of Central America: biological versus geophysics. Global Ecology and Biogeography Letters, 4: 169172.

Burns, P. \& A. Everly. 2000. Preliminary protocol for preparing fish skeletons. Available from:

www.mcz.harvard.edu/Departments/Fish/skeltechnique.htm (23 October 2000).

Castro-Aguirre, J. L., H. S. Espinosa Pérez \& J. J. Schmitter-Soto. 1999. Ictiofauna estuarino-lagunar y vicaria de México. México, D.F., Limusa-Noriega.

Chávez-Lomelí., M. O., A. E. Mattheeuws \& M. H. Pérez-Vega. 1989. Biología de los peces del Río San Pedro en vista de determinar su potencial para la piscicultura. Xalapa, FUCIDINIREB.

Collette, B. B. \& J. J. Russo. 1981. A revision of the scaly toadfishes, genus Batrachoides, with descriptions of two new species from the eastern Pacific. Bulletin of Marine Science, 31: 197-223.

Deckert, G. D. 1973. A systematic revision of the genera Diapterus and Eugerres: with the description of a new genus, Schizopterus (Pisces: Gerreidae). Unpublished Masters' Thesis, Northern Illinois University, Dekalb, 74 p.

Deckert, G. D. \& D. W. Greenfield. 1987. A review of the western Atlantic species of the genera Diapterus and Eugerres (Pisces: Gerreidae). Copeia, 1987: 182-194.

Elliot, N. G., K. Haskard \& J. A. Koslow. 1995. Morphometric analysis of orange roughy (Hoplostetus atlanticus) off the 
continental slope of southern Australia. Journal of Fish Biology, 46: 202-220.

Gaspar-Dillanes, M. T. 1996. Aportación al conocimiento de la ictiofauna de la selva Lacandona, Chiapas. Zoología Informa, 33: 41-54.

Gilmore, R. G. \& D. W. Greenfield. 2002. Gerreidae. Vol. III. Pp. 1506-1521. In: K. E. Carpenter (Ed.). The living marine resources of Western Central Atlantic. Rome, FAO species identification guide for fisheries purposes and American Society of Ichthyologist and Herpetologist. Special Publication, $\mathrm{n}^{\circ} .5$.

González-Acosta, A. F. 2005. Estudio sistemático y biogeográfico del género Eugerres (Perciformes: Gerreidae). Unpublished Ph.D. Dissertation. Centro Interdisciplinario de Ciencias Marinas, IPN, La Paz, Baja California Sur.

González-Acosta, A. F., J. De La Cruz-Agüero \& J. L CastroAguirre. 2005. A review of eastern Pacific species of the genus Eugerres (Perciformes: Gerreidae). Bulletin of Marine Science, 76: 661-673.

González-Acosta, A. F., J. De La Cruz-Agüero \& J. L. CastroAguirre. 2007. A review of the marine western Atlantic fish species of the genus Eugerres (Perciformes: Gerreidae). Bulletin of Marine Science, 80: 109-124.

Herzig-Strachil, B. 1997. Franz Steindachner (1834-1919) and other prime contributors to the Ichthyological Collection of the Naturhistorisches Museum Wien. Pp. 101-108. In: Pietsch, T. W. \& W. O. Anderson Jr. (Eds.). Collection Building in Ichthyology and Herpetology. Kansas, American Society of Ichthyologists and Herpetologists. Special Publication, $n^{\circ} .3$.

Hubbs, C. L. \& K. F. Lagler. 1964. Fishes of the Great Lakes Region. Ann Arbor, University of Michigan Press, 213 p.

ICZN. 1999. International Code of Zoological Nomenclature. $4^{\text {th }}$ Ed. London, The International Trust for Zoological Nomenclature.

Jordan, D. S. \& B. W. Evermann. 1927. New genera and species of North American Fishes. Proceedings of the California Academy of Sciences (Ser. 4), 16: 501-507.

Lovejoy, N. R. \& B. B. Collette. 2001. Phylogenetic relationships of New World needlefishes (Teleostei: Belonidae) and the biogeography of transitions between marine and freshwater habitats. Copeia, 2001: 324-338.

Lozano-Vilano, M. L., M. E. García-Ramírez, S. Contreras \& C. Ramírez-Martínez. 2007. Diversity and conservation status of the ichthyofauna of the Río Lacantún basin in the Biosphere Reserve Montes Azules, Chiapas, México. Zootaxa, 1410: 4353.

Lundberg, J. G., P. G. Sullivan, R. Rodiles-Hernández \& D. A. Hendrickson. 2007. Discovery of African roots for Mesoamerican Chiapas catfish, Lacantunia enigmatica, requires an ancient intercontinental passage. Proceedings of the Academy of Natural Sciences of Philadelphia, 156: 39-53.

McEachran, J. D. \& J. D. Fechhelm. 2005. Fishes of the Gulf of Mexico. Vol 2. Scorpaeniformes to Tetraodontiformes. Austin, University of Texas Press.

Meek, S. E. \& S. F. Hildebrand. 1925. The marine fishes of Panama. Part II. Field Museum of Natural History, Publication No. 226. Zoological Series 15: 331-707.

Miller, R. R. 1966. Geographical distribution of Central America freshwater fishes. Copeia, 1966: 773-802.

Miller, R. R. 1982. Pisces. Pp. 486-501. In: Hulbert, S. H. \& A. Villalobos-Figueroa (Eds.). Aquatic Biota of Mexico, Central America and the West Indies.. San Diego, San Diego State University Press.
Miller, R. R. 1986. Composition and derivation of the freshwater fish fauna of México. Anales de la Escuela Nacional de Ciencias Biológicas, 30: 121-153.

Miller, R. R. \& M. L. Smith. 1986. Origin and geography of fishes of the Central Mexico. Pp. 487-517. In: Hocutt, C. H. \& E. O. Wiley (Eds.). The Zoogeography of North American Freshwater Fishes. New York, John Wiley \& Sons.

Miller, R. R., W. L. Minckley \& S. M. Norris. 2006. Freshwater fishes of México. Chicago, The University of Chicago Press, 490 p. [copyright date 2005; published in 2006].

Nelson, J. S., E. J. Crossman, H. Espinosa-Pérez, L. T. Findley, C. R. Gilbert, R. N. Lea \& J. D. Williams. 2004. Common and scientific names of fishes from the United States, Canada, and Mexico. $6^{\text {th }}$ ed. Bethesda, American Fisheries Society, Special Publication.

Raven, P. H. \& D. I. Axelrod. 1979. Angiosperm biogeography and past continental movements. Annals of the Missouri Botanical Garden, 61: 539-637.

Rodiles-Hernández, R. 2005. Diversidad de peces continentales en Chiapas. Pp. 195-220. In: M. González-Espinosa, M., N. Ramírez-Marcial \& L. Ruiz-Montoya (Eds.). La diversidad biológica de Chiapas. Chiapas, Plaza y Valdés, ECOSUR, COCYTECH.

Rodiles-Hernández, R., E. Díaz-Pardo \& J. Lyons. 1999. Patterns in the species diversity and composition of the fish community of the río Lacanjá, Chiapas, México. Journal of Freshwater Ecology, 14: 465-468.

Rojo, A. L. 1991. Dictionary of evolutionary fish osteology. Boca Raton, CRC Press, 273p.

Sabaj Pérez, M. H. 2012. Standard symbolic codes for institutional resource collections in herpetology and ichthyology: an Online Reference. Version 3.0 (23 February 2012). Electronically accessible at http://www.asih.org/, American Society of Ichthyologists and Herpetologists, Washington, DC.

Salgado-Maldonado, G. 2006. Checklist of helmint parasites of freshwater fishes from Mexico. Zootaxa, 1324: 1-357.

Savage, J. M. 1982. The enigma of the Central American herpetofauna: dispersals or vicariance? Annals of the Missouri Botanical Garden, 69: 464-547.

Sokal, R. R. \& F. J. Rohlf. 1981. Taxonomy congruence in the Leptopodomorpha reexamined. Systematic Zoology, 30: 309325.

Steindachner, F. 1863. Über eine neue Gerres. Verhandlungen der K.K. Zoologisch-botanischen Gesellschaft in Wien, 13: 383384.

Taylor, W. R. \& G. C. van Dyke. 1985. Revised procedures for staining and clearing small fishes and other vertebrates for bone and cartilage study. Cybium, 9: 107-119.

Velasco Colín, R. 1976. Los peces de agua dulce del Estado de Chiapas. Tuxtla Gutiérrez, Ediciones del Gobierno del Estado

Submitted August 15, 2012 Accepted March 16, 2013 by Marcelo Britto Published June 28, 2013 